\title{
From Pluralism to Multiculturalism: Challenges in Indonesia
}

\author{
Heddy Shri Ahimsa-Putra \\ \{heddy.shri@ugm.ac.id\} \\ Universitas Gadjah Mada, Indonesia
}

\begin{abstract}
It is argued in this paper that Indonesian society is no longer a plural society in the sense that Furnivall defined in 1950s. Using Blum's definition of multiculturalism, the author says that Indonesian society is not yet a multicultural society either, although its national motto is "unity in diversity". Some facts are given for this. It is proposed that to improve the process of creating a multicultural society, certain strategies need to be employed in some fields, such as: education; promotion; and social media.
\end{abstract}

Keywords: Multiculturalism, Pluralism, Challenges, Strategies

\section{Introduction}

In Indonesian context, discussing multiculturalism needs to be done carefully, because the two English words with very different meanings, namely pluralism and multiculturalism are usually translated with the same Indonesian word, that is kemajemukan, or sometimes keanekaragaman. In fact, in academic discourse, pluralism has a very different meaning from multiculturalism. This needs to be a serious concern of Indonesia social scientists, because translating these two words into one word will result in confusion of meaning, which will then become an obstacle to efforts to build a multicultural society.

In this paper I convey the view that Indonesian society is no longer a plural society, such as stated by Furnivall [1] in the middle of the last century, but it is not or not yet a multicultural society either. However, Indonesia needs to become a multicultural society - what I call a bhinneka society - if national unity is to be maintained. Although Indonesia has made "unity in diversity" the motto of the state, the realization of this motto is not an easy thing. A number of obstacles must be overcome if this bhinneka or multicultural society is to truly be realized.

\section{Pluralism and Multiculturalism}

The concept of plural society -which is sometimes interpreted as "pluralism" became popular in social science after Furnivall [1] used it in his observation of Southeast Asian society in 1950, to describe the state of society in the region, which consists of various ethnic groups living side by side, but not always knowing and understanding each other, although they lived under the same political system. The social contacts among these ethnic groups were relatively limited, and generally took place only in the market or due to practical needs. The market thus became an arena for knitting relations between groups or tribes. 
Now, the meaning of this concept has expanded more widely. There are several meanings of 'pluralism' in the study of society and culture, and social scientists do not always agree on which meaning should be used in their researches. Van den Berghe [2] had described in sufficient detail the development of the study of pluralism in social science. Here I am taking a rather general and less complicated view of 'pluralism', which I translate in Indonesian as kemajemukan. This translation is actually not quite appropriate, because the '-ism' in 'pluralism' actually refers to a certain view, opinion or thought, while kemajemukan refers more to a situation, condition or characteristics. However, for the moment we will ignore this problem.

Pluralism in a rather simple sense, as explained by Van den Berghe [2], refers to a number of characteristics of a society. These characteristics include (1) the existence of social groups or cultural groups; namely groups with different cultures; (2) these groups coexist (3) within the boundaries of a polity or political unit and (4) have a common economic system, which makes these groups dependent on one another. Even so, these groups are more or less (5) autonomous and have different order structures in other spheres of life, such as kinship, religion, and so on.

Therefore, the image of a plural society is quite similar to a 'mosaic'. A mosaic consists of fragments with different colors, some of which are more or less similar to one another. These pieces are held together by the glue stick and the whole combination represents a particular image. This adhesive may or may not be very strong. If this mosaic is broken, the elements that make up the mosaic will be separated again. Thus, a pluralistic society is a society in which cultural and social segregation are clearly visible. The segregation is due to differences in culture or social characteristics between the groups that make it up.

In other contexts, especially in political discourse in the United States, pluralism refers to a view that recognizes differences in ideals or philosophies regarding politics, life and religion [3][4]. The meaning of pluralism here is different from the meaning of plural society as suggested by Furnivall, in his study of Southeast Asian society.

Much effort has been made to define the concept of multiculturalism [5][6]. One of the definitions that in my opinion is relatively easy to apply in research and development of multiculturalism in everyday life is the one proposed by Blum [7] in an article published in Etika Terapan. It says that multiculturalism as an understanding, respect and appreciation for the culture of others, other societies. A respect accompanied by curiosity, the desire to know and understand other cultures. Even though it is a respect, respect for cultural differences, it does not mean agreeing with all aspects or elements of the different culture. In this sense, multiculturalism is nothing but an element of a certain set of values.

As an element of a set of values, multiculturalism contains three sub-values, namely: "(a) affirming one's cultural identity, studying and assessing one's cultural heritage; (b) respect and desire to understand and learn about (and from) cultures other than theirs; (c) evaluate and feel happy with any cultural differences; seeing the existence of different cultural groups in one's society as a positive thing to be appreciated and maintained [7].

To avoid misunderstanding Blum further explained that the type of respect for point (b) is meant as "respect with knowledge (and not without criticism), which is based on an understanding of other cultures. It includes attempts to see culture from the point of view of its members and, in particular, to see how members of that culture value the expressions of their own culture. It includes an active sense of interest and the ability to enter and enjoy the cultural expressions of other groups" [7].

If multiculturalism has become part of the value system of a society, it can be said that multiculturalism has become a social consciousness. A multicultural society is a society that clearly has a tradition of understanding, valuing and respecting the culture of others. Multiculturalism is said to be stronger if the respect does not stop at respect only, but also grows 
into a desire to understand the culture of another society or ethnic group, including "an appreciation .... not in the sense of agreeing to all aspects of these cultures" but "...trying to see how a particular culture can express values for its own members" [7]. If these things have been successfully achieved by a society, then such a society is a multicultural society. It has multicultural awareness, because it has turned multiculturalism as part of their social awareness.

With such an understanding of pluralism -or more precisely, plural society and multiculturalism, we may try to understand what is Indonesian society like today? Is it a society that is both plural and multicultural? Or multicultural but not plural? Or neither?

\section{Indonesian Society: No Longer Plural, Not Yet Multicultural?}

Although Indonesians are generally proud of -and sometimes boast- the diversity of cultures in their country, the various conflicts between groups and/or ethnic groups occurred in the last ten to fifteen years show that this pride seems to only apply to certain circles, at certain social layers of the society, namely the middle class. At the lower social level, this pride is actually still thin. There is no sufficient deep understanding of the existing cultural variations among the members of this class. Therefore, the pride immediately disappears when the interests of one's group or groups are threatened by the presence of other groups. Multicultural values will be easily removed because they are considered irrelevant, if they are not weakening or detrimental. These various conflicts seem to confirm to us that our society is indeed plural, but not yet multicultural. The multicultural awareness of our society is still low.

In addition to that, the low level of multiculturalism in our society -in my view- is also reflected in the following facts.

\subsection{Lack of Understanding of Other Cultures/Religions}

Many of us, Indonesians, generally do not understand other cultures, and this is not too surprising, since the understanding of even their own culture is mostly low. Among the Javanese, for example, we find that even though the people know that their language has three levels of speaking (ngoko, krama madya and krama Inggil), it turns out that not all Javanese can use these three levels of language well enough. If the knowledge on the most fundamental means of communication in one's own culture is low, let alone knowledge of other cultural elements that are not as important as language; let alone knowledge of cultural elements that exist in other cultures.

In Indonesia, although a person lives side by side with members of other ethnic groups or live in another culture, it does not necessarily make him understand the culture of the society in which he lives, especially if the culture comes from the past. Many Javanese have lived among the Acehnese, among the Minangs, among the Balinese, and so on, and vice versa. But how deep and broad do they know the cultures of the communities in which they live? Not deep nor broad enough, in my knowledge. That was the impression I got after I met people from various ethnic groups who have been living in other communities with different cultures.

Lack of understanding about other cultures is not only cultures from other places, but also from other times. A lot of Indonesians have seen Borobudur and Prambanan temples, have seen the Javanese Kraton, but how many of those who have visited then know and understand the culture of the people who made these temples or know about the Kraton culture? Not many, I guess. How many members of our society interested in history visit museums to see the culture 
of their own people living in different countries? How many of us are we interested in building museums about societies in the past and today's society (which one day will become the society of the past)? Lack of interest in the culture of the past and the cultures of other societies today can clearly be seen in Indonesian society in general, and this is a sign of the low multicultural aware-ness in our society.

\subsection{Lack of Desire to Study Other Cultures/Religions}

Indonesians are generally less interested in learning and understanding the cultures of other ethnic groups. If there is such an effort, it is not done systematically that the understanding gained is often tinged with elements of ethno-centrism. The desire to study other societies or cultures only grows in certain circles, which drive them apply for entrance to arts academy or departments focused on language and culture.

My experience with students and cultural enthusiasts gives the impression that they are generally interested in studying their own culture and society first. This also happens among anthropology students who should have the greatest demand to know and understand cultures outside their own society. The low interest in studying other cultures in this case might be related to the high cost of conducting research among different ethnic groups in other places.

\subsection{Lack of Respect for Other Cultures/Religions}

Lack of understanding and the desire to learn about other cultures has further made our respect for the cultures of other ethnic groups not so high. Ethnocentrism is generally still firmly attached to us, Indonesians, and this is usually reflected quite clearly, and manifested shamelessly, in various "slanted" comments about the customs of other ethnic groups. Even this unpleasant view often afflicts the arts of certain ethnic groups, even though art is an expression of ideas and a sense of the divinity of a particular society through movements, sounds or pictures. Often this lack of respect for other cultures is manifested in the form of excessive praise given to one's own culture.

We can still add various other examples of the low level of multiculturalism in our society, provided we are willing to pay close attention to the things around us and reflect on them. I think we need to do serious and empirical research on the level of multiculturalism in Indonesia, because Indonesians tend to think that they are used to living in diversity, in plurality, and feeling proud of it, so that they think that their cultural consciousness is unquestionable. In fact, living in a society full of differences is not always accompanied by an attitude of life that is more respectful and appreciative of these differences. The emergence of halal tourism (pariwisata halal) as well as its intention to make Bali a place for such tourism is one the clearest example and the most recent one.

\subsection{Low Multiculturalism: Which Social Strata?}

Accepting the definition of multiculturalism as certain sets of values, which seem new to most of our fellow Indonesians, the question then is whether that low level of multiculturalism exists at all levels of our society or only at certain social strata? If multiculturalism is a set of values, and these values are generally better known in the world of formal education, then the temporary conclusion we can draw is that the social strata or groups which are relatively untouched by formal education, tend to have a low level of multiculturalism. 
Various conflicts occurred in the last few years seem more or less support this view, even though in certain locations or in certain cases this opinion has not been proven at all. The conflicts so far seem to (in general) involve those who are in the lower or lower middle social strata, which in the education map of Indonesia is a layer with a low level of education. In this layer, according to my observations, multicultural consciousness is indeed relatively lower than other social strata. Even so, when compared with people in several developed countries, the overall multicultural level of our society seems to be lower. Of course, to ensure the validity of this impression, a more serious and in-depth scientific research is needed.

\section{Multicultural Awareness}

If we agree that multiculturalism is a set of values necessary for a nation as diverse as Indonesia, our next question is: is it possible for us to knit multiculturalism in Indonesia? What strategies need to be taken to knit a tapestry of multiculturalism on which we can sit on the floor together?

Multiculturalism as an ideal set of values will only be able to produce a good life if they are used as guidelines in our behavior, in interacting with other individuals. In a society that is not familiar with the idea of multiculturalism, these values are clearly new ones, which are not always easy to accept. In order for these values to become part of the existing set of values, it is necessary to build a new awareness in our society, through which we will be able to weave a new network of meanings. In the end, this multiculturalism set of values should be able to produce new following awareness:

\subsection{Awareness of the Errors of Ethnocentrism}

With the launching of the multiculturalism value set above, ethnocentrism -a principle saying that the use of a frame of thought, a set of knowledge, a set of values originating from one's own culture to judge everything is an appropriate action- then must be reviewed, even interpreted as negative, because the values in ethnocentrism are the opposite of multiculturalism. Ethnocentrism needs to be seen as a set of values that will lead a society or community towards exclusivism, which will further reinforce the socio-cultural boundaries of a com-munity with other communities. This will make it more difficult to create a healthy social integration based on mutual need and exchange. Unconscious ethno-centrism will also lead to an attitude of glorifying one's own culture, degrading other cultures, lack of respect for other cultures, which in turn will lead to a lack of respect for the people who support those cultures.

\subsection{Awareness of the Importance of Multicultural Values}

The values of multiculturalism then also need to be well understood and need to be viewed as a set of values that is more suitable for a society consisting of many ethnic groups, such as Indonesia. People should be more aware of the need to know, understand and appreciate different opinions; understand and appreciate different cultures, so that the tendency to give ethnocentric judgments could be reduced. People also need to realize that it is multiculturalism that will allow and support cultural diversity to exist and be respected. In addition, understanding and respect for different cultures must really be carried out consciously and systematically. It is only with this understanding that the threads of the values of 
multiculturalism can be woven together into a tapestry of multiculturalism, on which every social group, ethnic group or communities of different traditions can stand the same height, sit at the same low, and enjoy a meal of cultural diversity.

\subsection{Awareness of the Need for Socio-Cultural Sensitivity (Tepa-Slira)}

It is also hoped that the values of multiculturalism will be able to make people more sensitive, more able to feel the need for a set of proper values in life together with those who are different in culture and outlook on life. It means that if we don't like to be hit, we should not hit either; that if we don't like being treated a certain way, so will other people. This is what is known among the Javanese as the principle of tepa slira by adhering to the principle of tepa slira, everyone will be more careful and have more respect for other people, other groups, or other cultures.

Such socio-cultural sensitivity will also be able to prevent people from being abusive or looking down on other cultures that are different, or which appear more modest. Abusive attitudes can not only infect members of a dominant culture in certain area, but also members of social strata who have an exclusive culture and feel higher or treated higher than other social strata. Multicultural awareness seems would make supporters of a particular culture wiser and more able to appreciate other different cultures, even though the culture looks much simpler.

\section{Building Multicultural Awareness}

Those multicultural values and the awareness of them cannot be allowed to grow on their own, because it is a new social phenomenon, if they are expected to produce a multicultural society as desired. Several strategies need to be taken to develop social awareness on multicultural values, including socializing them through the following paths:

\subsection{Education}

Multicultural values that respect cultural differences, accompanied by a desire to learn them, have to be introduced to school students from elementary to high school levels [8]. This should of course use the appropriate methods of teaching and learning appropriate to their level of cognitive development [9][10]. Students can learn various cultural variations in Indonesia and what the benefits of this cultural diversity are for the life of a nation and humanity in general.

Students can also be invited to visit various ancestral cultural relics, such as the Borobudur, Prambanan, Dieng temples, and so on, from which they can get some understandings of the values of the society that had built those magnificent buildings. Students can instill a curiosity that will make them interested in learning about and appreciating the culture of their ancestors.

\subsection{Public Spaces}

In public spaces, billboards can be installed which remind citizens of the multicultural values that need to be preserved and developed in everyday life. With a variety of sophisticated and interesting presentation techniques, multicultural messages will slowly be embedded in the consciousness of citizens. If cigarette advertisements that can have a negative impact on health 
are let to color billboards in public spaces, the presence of multiculturalism advertisements that have a positive impact on people's lives should be felt even stronger.

\subsection{Social Media}

Multicultural values can also be socialized through social media, as well as advertisements for various products. Social media is one of the most practical means of reaching a wide public. Of course, it is necessary in this case to design various multiculturalism advertisements that are suitable for the targeted community. There are multiculturalism advertisements for millennial generations, there are also advertisements for older generations.

Space and time do not allow me to discuss at length the various strategies above. Other strategies can be added, such as making films and TV series with the theme of multiculturalism, holding seminars on multiculturalism, writing articles in newspapers about multiculturalism, publishing results of research on multiculturalism, holding exhibitions, etc.

\section{Closing Remarks}

In this paper I propose a provisional opinion -based on daily observations and experiencesthat, first, the understanding of pluralism and multiculturalism among Indonesian socio-cultural scientists is still inappropriate. There is still confusion in using the concepts of pluralism and multiculturalism. This confusion seems to have made our analysis and understanding of Indonesian society less precise, less tidy and less systematic. If this is allowed to drag on, it is not impossible that our way of dealing with various problems of cultural pluralism will also be inappropriate, otherwise it will be detrimental at all.

Second, Indonesian society is indeed a plural society, but not in the sense that Furnivall used in the past. It consists of various ethnic groups and cultures, but is not yet multicultural. This can be seen from the low desire among its members to know and understand other cultures, as well as from their low understanding and respect for different cultures. The lowest multicultural aware-ness seems to be at the lowest social strata as well. To overcome this, it is necessary to take steps that can increase multiculturalism awareness in our society.

Third, because multiculturalism is a relatively new set of values for our society, efforts are needed to build these values in society so that: (a) ethnocentrism does not flourish in it; that (b) our society understands and accepts the values of multiculturalism, and that (c) our society has a higher sensitivity regarding cultural differences in everyday life.

\section{References}

[1] J. S. Furnivall, "Colonial Practice and Policy." Cambridge: Cambridge University Press, 1948.

[2] P. L. van den Berghe, "Pluralism," in Handbook of Social and Cultural Anthropology, J. J. Honigmann, Ed. New York: MacMillan, 1970.

[3] D. C. Williams, Pluralism. Encyclopedia Americana 22, 1973.

[4] A. O. Rorty, "Varieties of pluralism in a polyphonic society," Rev. Metaphys., pp. 3-20, 1990.

[5] J. Citrin, D. O. Sears, C. Muste, and C. Wong, "Multiculturalism in American public opinion," Br. J. Polit. Sci., pp. 247-275, 2001.

[6] T. B. Powell, "All colors flow into rainbows and nooses: The struggle to define academic multiculturalism," Cult. Crit., no. 55, pp. 152-181, 2003.

[7] L. A. Blum, "Antirasisme, Multikulturalisme, dan Komunitas antar Ras: Tiga Nilai yang Bersifat 
Mendidik bagi Sebuah Masyarakat Multikultural,” May, S. Collins-Chobanian K. Wong [eds]. Etika Terap. I Sebuah Pendekatan Multikultural. Yogyakarta PT Tiara Wacana Yogya, Terjemahan, hlm, pp. 15-25, 2001.

[8] L. Y. Matuk and T. Ruggirello, "Culture Connection Project," Can. J. public Heal., vol. 98, no. 1, pp. 26-29, 2007.

[9] W. M. Chace, "The Real Challenge of Multiculturalism (Is Yet to Come)," Academe, vol. 76, no. 6, pp. 20-23, 1990.

[10] P. Rothenberg, "Beyond the food court: Goals and strategies for teaching multiculturalism," Fem. Teach., pp. 61-73, 2000. 